\title{
THE DYNAMICS OF PROFESSIONAL IDENTITY OF UNIVERSITY TEACHERS: REFLECTING ON THE IDEAL UNIVERSITY TEACHER
}

ANU HAAMER, LIINA LEPP

University of Tartu, Estonia

ELINA REVA

Tallinn University, Estonia

\begin{abstract}
Current paper investigates development of professional identity of university teachers, observed through reflective exercises which enabled participants' to focus on their perception of the ideal university teacher. Images of the ideal university teacher were studied from two aspects: first - before the participants started teaching, and second - after they had been teaching for some time. This paper focused on how images of the ideal university teacher have changed over time, and discussed the reasons that brought about changes. There is a tendency that ideals are adapted in accordance with teaching experience. Ideals are regarded as unstable phenomena, influenced by the surrounding environment. Current paper made use of a qualitative design of reflective writing exercises and focus group interviews. The sample comprised an aggregate of 42 participants, university teachers and $\mathrm{PhD}$ students, and 4 focus groups. Interviews were analyzed using qualitative content analysis. The study shows that after some teaching experience, didactic knowledge and communicative skills come to the forefront of the ideal university teacher identity. The study opens the way
\end{abstract}

for further and deeper discussion of images of an ideal university teacher.

Keywords: dynamics of identity, ideal image, ideal university teacher, professional identity, reflection

\section{INTRODUCTION}

Social, economic and political changes have challenged the objectives of classical education and have led to considerations as to what the character of ideal teachers should be like, and how they should be prepared (Cochran-Smith \& Fries, 2001). There is an increasing need in that field to pay more attention to reflective activities. Reflection is generally acknowledged as an important part of teacher education and a central activity in teacher development. Close connections between reflection and identity development have been noted in literature on teacher education (Beauchamp \& Thomas, 2010; Loughran, 2002).

Reflection helps an individual to become more aware of their own aspects, which impact on their professional development. Aspects influencing the development of professional identity are closely connected to

ANU HAAMER is an academic developer and a lecturer in the Institute of Education at the University of Tartu. Her main research interests are the identity development and reflection of university teachers.

LIINA LEPP is a lecturer and a PhD student in the Institute of Education at the University of Tartu. Her main research interests are teacher professional development and reflection.

ELINA REVA is a lecturer and PhD student in the Institute of Educational Sciences at the Tallinn University. Her main research interests are the reflection, self-concept and self-regulation of university teachers. 
perceptions about the ideal-self as a professional, as well as concepts that this ideal professional is based on (Verhofstadt-Deneve, 2003; Day, 1998).

Examination of the image of an ideal teacher helps to understand the dynamics of the development of professional identity of a teacher and will help to understand how to support university teachers through various activities meant to support them.

The aim of the study was to investigate the image of an ideal university teacher and changes in the ideals by means of a variety of reflective activities. This research focused on issues dealing with how the image of the ideal teacher has changed over time, and on the reasons bringing about these changes. In order to appreciate this, we attempted to answer the following questions:

- What is the perception of the ideal university teacher like before actual teaching?

- What is the perception of the ideal university teacher like after teachers had been teaching for some time?

- How has the image of the ideal university teacher changed over time and how do teachers rationalise and explain the change?

Studying the university teacher's ideal image through reflection enables the gathering of information about the dynamics of professional identity development of the university teacher (Beauchamp \& Thomas, 2010).

Since one of the reflections of the university teacher's professional identity is the image of an ideal teacher, a sensible course of action would be to initially examine various treatments of the concept of professional identity. From a broader identity-theoretical background it is then possible to move on to a narrower thematic research on reflection and ideals.

\section{DEVELOPMENT OF PROFESSIONAL IDENTITY AND REFLECTION ON IDEALS}

\section{Professional identity}

Based on the social-constructivist treatment, the concept of identity is defined as a socially and culturally constructed self that is formed during the life course by lived experiences and by talking about these experiences with oneself (inner speech) and with others (Swennen, Volman \& Essen, 2008). Important issues in the study of identity are the degree of consciousness people have of their identities and the amount of agency that they have in their 'construction'.
Identity, rather than being innate, develops throughout an individual's life (Beijaard, Meijer \& Verloop, 2004), through relational issues as opposed to being a fixed attribute. Construction of identity is inclusive: each person participates in several, more or less separated, socially and culturally constructed worlds, which are socially organized and are reproduced continuously (Swennen et al., 2008). Identity development occurs in an inter-subjective field and can best be characterized as an ongoing process, a process of interpreting oneself as a certain kind of person, and being recognised as such in a given context (Gee, 2001). According to Wenger (1998), identity is shaped through participation, intentionally and non-intentionally, in various communities of practice.

Interpretation of professional identity can be viewed as a form of argument that is used by the individual to motivate, explain and provide meaning to one's activity, situations and values while representing one's profession. Professional identity as social identity is one of the aspects of individual self-concept that is constructed in the social context through dialogue between self and external reality (Hermans \& Dimaggio, 2007). Development of professional identity is comparable to the positioning of self in social space. However, such positioning is only relative, meaning that people know where and who they are when knowing their 'proper' relationship with others. In such social space people can think of themselves as being aware of an array of possible choices in various fields. By choosing some and rejecting other possibilities in various professional fields of choice, an individual affirms affiliations and makes distinctions that constitute an important part of their professional identity (Coldron \& Smith, 1999).

In the context of research into teachers' professional identities, we notice that whereas the development and professional identity of school teachers have been thoroughly studied (e.g. Flores \& Day, 2006; Stenberg, 2010; Akkermann, 2011), the development of university teachers' identity has been investigated on smaller scale (e.g. Archer, 2008; Clegg, 2008; Lea \& Stierer, 2009). When discussing the development of professional identity of university teachers, we relied on studies, which investigated both (school teachers and university teachers) at the same time.

According to Kreber (2010), teacher identities are shaped by a dynamic interaction between personal theories of teaching and perceptions of self (e.g. perceived self-concept and self-efficacy), which are both influenced by social and occupational contexts.

In a rapidly transforming global society, teachers are experimenting with their roles and re-creating their professional identities in relation to the contexts that surround them, sometimes shift in unexpected ways. 
This reality can make the development of a strong professional identity even more complex for new teachers (Thomas \& Beauchamp, 2011).

Identity formation can be seen as a process of practical knowledge building characterized by an ongoing integration of aspects that individually and collectively are seen as relevant to teaching. Identity formation is known as ongoing process of interpretation and re-interpretation of experiences (Beijaard, Meijer \& Verloop, 2004; Beijaard, Verloop \& Vermunt, 2000) and is called as dynamic and subject to a continuous learning process where personal history, social interactions and psychological and cultural factors influence the identity formation (Lamote \& Engels, 2010).

MacLure (1993) recognizes that self and identity are central sources and resources for undertaking teaching and engaging in professional development. She argues that identities are used by teachers to explain, justify and make sense of themselves in relation to others and to the world at large. Teacher identity is based on the core beliefs one has about teaching and being a teacher, beliefs that are continuously formed and reformed through experience.

Development of professional identity depends on the recognition of various aspects that shape identity and reflection is the activity that helps to support such a process of analysis and to bring identity into consciousness.

\section{Reflection on ideals}

The close connection between reflection and identity development has been noted in recent literature on teacher education (e.g. Loughran, 2002; Freese, 2006).

According to Johns (1995) the reflection process enables individuals to understand and evaluate an experience, hence learning from it. Korthagen \& Vasalos (2005) understand reflection as a subject's actionbased knowledge-building process that is influenced by the surrounding social reality and the subject's inherent qualities

Farrell (2009) identified reflection as a key component associated with the concept of self because it brings tacit conceptualizations to a level of awareness. In other words, it is impossible to speak about the self when there is no reflection.

Lamote and Engels (2010) note that in the course of the development of university teachers' professional identity, it is essential for the latter to reflect also on the kind of teachers they want to be. The prospective elements in reflection include the future perspectives the teachers have about their job and their profession- al development (Beijaard et al., 2004). While retrospective reflection relies on memory, anticipatory reflection contains an element of imagination, a looking forward to a future possibility that the student teacher might construct (Beuchamp \& Thomas, 2010).

Aspects that influence the development of professional identity are closely connected with perceptions about ideal-self as a professional and concepts that this ideal professional is based on (VerhofstadtDeneve, 2003; Day, 1998). According to Laurila and Kukkonen (2003), a teacher's identity development can be seen as finding a harmony, and coping with the conflicts between the ideal self, the ought self and the actual self.

Consequently, in the development of the teacher's professional identity an analysis of the existing actual self and the imagined ideal self through reflection plays a major role. Therefore, from the aspect of studying the development of professional identity it is essential to investigate the image of an ideal teacher that helps to understand the dynamics of the developmental process of the teacher (Beauchamp \& Thomas, 2010).

The ideal identity of a person consists of ideal images of whom they would like to be (Ruyter \& Conroy, 2002). According to Arnon and Reichel (2007), every teacher carries within them an image of ideal teachers and their qualities, skills and abilities. For teachers, this image represents a model to relate to, as it provides criteria to aspire to, aim for and act in accordance with.

The image of ideal represents a measure of evaluation of a teacher's practical activity - both personal and professional. It represents an "ideal" that serves as possible future and a sum total of a teacher's desired qualities.

The latter idea is also supported by the theory of possible-selves (Markus \& Nurius, 1986), which describes the importance and dynamics of self-relevant, future-oriented self-concepts, and how these self-views relate to motivation for present and future action. These self-concepts pertain to how individuals think about their potential and about their future, and may reflect an individual's expectations including hopes, aspirations, fears, and threats that they anticipate in the near or distant future (Hamman, Gosselin, Romano \& Bunuan, 2010; Markus \& Nurius, 1986).

Markus and Nurius (1986) hold the view that possible selves serve important functions resulting in the direction of current behavior. These future-oriented selves also represent the 'image' one would like to become (hoped-for selves) and they act as 'behavioral blueprints'. In addition to this informational 
feature, possible selves may also exert a motivational influence. Individuals with the foresight of what they want to become, may be more likely to persevere in pursuing their goals and aspirations (Hamman et al., 2010).

Holding an ideal of their future selves and recognizing the varying influences that may affect the achievement of the future selves may be a way to help teachers monitor their own progress (Beauchamp \& Thomas, 2010).

Fletcher (2000) describes how teacher ideals can be transformative both by imagining a specific goal for oneself as a teacher in the future (e.g. caring, effective) and by the motivational benefit of striving to become the type teacher one values and anticipates.

As earlier researches indicate (e.g. Beauchamp \& Thomas, 2010; Hamman et al., 2010; Arnon \& Reichel, 2007), investigating teacher ideals and their dynamics yields information about their professional identity as earlier researchers indicate the perception of the good teacher has pointed out personal qualities as important components of the ideal teacher. According to Ruyter and Conroy (2002), most Bachelor of Education students mentioned personality traits like being patient, honest, opened and just being natural as the characteristics of their ideal teacher. Likewise, in Strage's (2008) research, the most cited characteristics used by undergraduates to portray their ideal professor were: knowledgeable, entertaining, caring and concerned about their students. An individual's personal learning experience in the context of their experiences, (positive or negative), of school or university teachers will not only influence their image of, but will also form their cognition of, an ideal school or university teacher.

In their research on teachers' perceptions of an ideal teacher, Miron (1983) and Arnon and Reichel (2007) also point out that the main attributes of an ideal teacher are an appropriate personality alongside professional knowledge consisting of both subject knowledge and didactic knowledge and skills. In their work on university teachers' notions of the attributes of an ideal university teacher, Karjalainen and Nissilä (2008) presented three main categories pedagogical competence, teacher personality, expert of subject knowledge.

This investigation concentrates on university teachers' concepts about the nature of an ideal university teacher. We are interested in the manner: that an individual characterizes the image of their ideal university teacher prior to doing any teaching in university; that image has changed after having done a certain amount of teaching; and in the reasons influencing that change. Reflective exercises are implemented for finding out which characteristics are used when de- scribing an ideal university teacher and the broader categories of the pertinent characteristics.

\section{METHODOLOGY}

\section{Participants and research instruments}

The participants were all Estonian and consisted of two groups: university teachers and Ph.D. students.

The university teachers' group $(\mathrm{n}=31)$ representing the University of Tartu and Tallinn University consisted of 25 women and 6 men. They had all been educated in the Estonian educational system; their average age was 42 years; and their average teaching experience at the university level was 5 years. The members of this group were participants of three reflection training groups for university teachers (T1, T2, T3), at Tartu and Tallinn University during 2009-2010.

The Ph.D. students' group $(n=11)$ the University of Tartu consisted of 9 women and 2 men. They had all been educated in the Estonian educational system; their average age was 35 years; none of the group had any teaching experience at the university level. The members of this group (D1) all participated in the university teaching course at Tartu University, which is obligatory for PhD students, during 2010.

We used reflective writing exercises and focus-group interviews as the data collecting methods. We asked both groups to do their reflective writing exercise at the beginning of their respective training courses to forestall the impact of the courses on the content of the written exercise.

We administered the reflective writing exercises in two parts. In the first part, we asked the participants in groups to think back to their own learning period or the time before they taught in the university and try to imagine the kind of personality traits that characterized an ideal university teacher at that time (discussed further in Results: Ideals 'before'). Participants were asked to use adjectives, adjective phrases and characteristics to describe an ideal university teacher.

In the second part, we asked only the group of university teachers to think about their current, 'now', imagined ideal of a university teacher, using adjectives, adjective phrases and characteristics (Discussed further in Results: Ideals 'now').

Authors conducted an in-depth check and substantial evaluation of the reflective writings and analyzed the data using qualitative content analysis with open coding (Strauss \& Corbin, 1990).

Based on the results of reflective writings, was created three focus group interviews for the university 
lecturer group and one focus group interview for the $\mathrm{PhD}$ student group. Focus group interview is suited for gather rich data and explain the meanings, beliefs and cultures that influence the feelings, attitudes and behaviours of individuals. It provides information about a range of ideas and feelings that individuals have, as well as shows the differences in perspective between groups of individuals (Rabiee, 2004). In the course of these focus groups the participants had the opportunity to explain and reflect on their points of view and to discuss the ideals, the subsequent changes and the influencing factors.

\section{Analysis}

For analyzing reflective writings qualitative content analysis, in which coding categories are derived directly and inductively from the raw data, was used. It gave researchers opportunity to understand social reality in a subjective but scientific way. For validation the content analysis, was carried out the process of extraction of categories separately and inclusively (Hsieh and Shannon, 2005).

Based on the data of ideal 'before' and ideal 'now' reflective writings, we identified five of the most frequently mentioned characteristics appearing in both sets of writings. We ascertained these characteristics by assembling adjectives of similar topics and contents. We chose the five that best conveyed the essence of the adjectives used by the participants.

For the focus group interviews we asked each participant to rank these five characteristics according to importance, in which the participant viewed them, and to discuss the reasons for their choices. We asked the university teachers' focus groups to clarify how their images of an ideal university teacher had changed over time and the factors that had brought about the changes.

We had the interviews fully transcribed and analyzed using qualitative content analysis.

Analysis of the focus groups' data revealed the existence of three major categories: knowledge of the subject, personal qualities and didactic knowledge.

The existence of these categories are supported by the research of Arnon and Reichel (2007) as well as Karjalainen and Nissilä (2008), which indicated the range of categories that comprise perceptions of an ideal teacher. The knowledge of the subject is naturally attributed to the university teachers. As researchers they may be context dependent, to a certain extent, in the sense that making what counts as a contribution to research may be more conditioned by the state of the research field than by practitioner or student needs for better understanding. Personal features mark the professional self, the core of which is, supposedly, a hierarchy of values, goals and standards which the individual has developed in order to make decisions. The didactic knowledge was explained mainly by describing various pedagogical measures in teaching, in some cases the reference was directly to teaching methods.

\section{RESEARCH FINDINGS}

Based on the analysis of reflective writings and the focus group interviews, the findings are presented in two main parts: (i) ideals "before" and (ii) ideals "now" and the changes.

\section{Ideals "before"}

The five most frequently used characteristics representing the ideal 'before' image of a university teacher mentioned in the reflective writing exercises were: excellent knowledge of the subject, dignity, skilful communication, interesting personality, and ability to present one's subject. These five characteristics comprised the three afore-mentioned categories of knowledge of the subject, personal qualities and didactic knowledge (see Table 1).

The participants' discussions in the focus groups ranked the five of the most frequently mentioned characteristics of writings in order of significance as: dignity, skillful communication and interesting personality were grouped under the category of personal qualities, ability to present one's subject made up the category of didactic knowledge and the third major category was excellent knowledge of subject.

There was little difference in the ranking of the ideal 'before' characteristics as discussed by either sets ( $\mathrm{PhD}$ and university lecturers) of focus groups or in the individual reflective writings.

Both sets of focus groups ranked great expertise in the subject as the most important feature of an ideal university teacher. They also agreed that the ideal university teacher must primarily have an excellent knowledge of the subject, followed by personal qualities, and then didactic knowledge.

Their comments clearly indicate that university teachers need to be excellent specialists in their subject, keep abreast with world scientific achievements in the field and, ideally, be world-renowned top scientists:

I remember the university teacher $X$ who was an idol for me, actually I was hanging on his lips, who was also a world-renowned scientist.

(University lecturer - T1) 
Table 1. CHANGES IN THE CHARACTERISTICS OF THE IDEAL UNIVERSITY TEACHER BETWEEN 'BEFORE' AND 'NOW' (AFTER) PRACTICAL TEACHING EXPERIENCE

\begin{tabular}{|c|c|c|c|}
\hline \multicolumn{2}{|c|}{$\begin{array}{l}\text { Image 'before', } \\
\text { before practical teaching experience }\end{array}$} & \multicolumn{2}{|c|}{$\begin{array}{l}\text { Image 'now', } \\
\text { after practical teaching experience }\end{array}$} \\
\hline \multicolumn{2}{|c|}{$\begin{array}{c}\text { Focus Groups } \\
\text { PhD students and University Lecturers }\end{array}$} & \multicolumn{2}{|c|}{$\begin{array}{l}\text { Focus Groups } \\
\text { University Lecturers }\end{array}$} \\
\hline Category & $\begin{array}{l}\text { Characteristics } \\
\text { (ranked by significance) }\end{array}$ & $\begin{array}{l}\text { Characteristics } \\
\text { (ranked by significance) }\end{array}$ & Category \\
\hline \multirow[b]{2}{*}{ Knowledge of subject } & (Rank 1) & (Rank 1) & \multirow[b]{2}{*}{ Didactic knowledge } \\
\hline & $\begin{array}{l}\text { Excellent knowledge of } \\
\text { subject }\end{array}$ & Ability to present subject & \\
\hline \multirow{2}{*}{ Personal qualities } & (Rank 2) & (Rank 2) & \multirow{2}{*}{ Personal qualities } \\
\hline & Dignity (self-respect) & Skillful communication & \\
\hline \multirow{2}{*}{ Personal qualities } & (Rank 3) & (Rank 3) & \multirow{2}{*}{ Personal qualities } \\
\hline & Skilful communication & Interesting personality & \\
\hline \multirow{2}{*}{ Personal qualities } & (Rank 4) & (Rank 4) & \multirow{2}{*}{ Personal qualities } \\
\hline & Interesting person & Dignity (self-respect) & \\
\hline \multirow[b]{2}{*}{ Didactic knowledge } & (Rank 5) & (Rank 5) & \multirow[b]{2}{*}{ Knowledge of subject } \\
\hline & Ability to present subject & $\begin{array}{l}\text { Excellent knowledge of } \\
\text { subject }\end{array}$ & \\
\hline
\end{tabular}

What else do you want but that the one who is delivering a lecture would first and foremost be a top-notch specialist. That's the reason for entering university - to get wiser under the guidance of wise people.

(PhD student - D1)

A person who gives a lecture has to know all about that particular field the lecture is on likewise, the lecturer has to be able to answer all the questions.

(University lecturer - T1)

Personal qualities were initially ranked second by all the focus groups. In their subsequent reflections the participants mentioned that while contemplating the ideal "before", they had concrete university teachers in their minds from the period of their own studies. The $\mathrm{PhD}$ students' explanations revealed it even more directly and in a number of cases pointed out that the image of an ideal university teacher could be related to both negative and positive examples about university teachers.

A university teacher has to impress the audience also as a person, not only as a specialist in a particular field - thus to be remembered by something.

(PhD student - D1)

All the focus groups' discussions of the ideals 'before' clearly ranked didactic knowledge last. Some participants were convinced that one does not think about didactic knowledge when not teaching.
The main thing is to acquire knowledge and in a possibly human way at that.

(University lecturer - T3)

PhD students also agreed that the manner in which a subject was taught was important, but less important than either subject or the teacher. They also contemplated the fineness of the border between personal qualities and didactic knowledge as there is a clear correlation between the manner in which a subject was taught was and the individual teaching it.

Some lecturer may read an excellent lecture, making everybody listen and think along - without any immediate "firework display", the other person may try and use various active teaching methods and yet finds it hard to make students think along and co-operate. Thus, didactic knowledge and personal qualities are definitely very closely related.

(PhD student - D1)

$\mathrm{PhD}$ students also deliberated on whatever they would gain as future university teachers when discussing and reflecting the characteristics of the ideal university teacher, concluding that the process offered the opportunity of realizing, which characteristics of a university teacher are evaluated and why, as well as seeing a connection between the process and self-development as a university teacher. 
Maybe there are qualities that I feel lacking in myself as a future university teacher - I may wish to be an "earnest scholar and practitioner", "pleasant and brilliant speaker" as well as "understanding and capable of supervising in the learning process".

(PhD student - D1)

\section{Ideals "now" and the changes}

During the focus group interview, after reflecting on ideals "before", we asked only the university teacher focus groups to rank the ideal "now" characteristics according to the significance they hold for them.

The findings show that the most important characteristic about ideals "now" was the ability to present the subject, followed by dignity, skillful communication and interesting personality and lastly, an excellent knowledge of the subject (see Table 1).

As Table 1 indicates, the order of significance of the five characteristics changed between the ideal 'before' and the ideal 'now'. The university lecturer focus groups discussed the reasons that might have caused the changes, presented by categories beginning with didactic knowledge.

They mentioned that as working university teachers they considered the development of teaching methods as highly important.

A university teacher has to connect with each individual student - be able to teach even the one who is not sufficiently motivated or has some other reason for not willing to study.

(University lecturer - T2)

I have realized that both for one's own sake as well as for the learners' sake study materials have to be systematized.

\section{(University lecturer -}

The focus groups also concluded they had understood the importance of thinking out and planning a lecture. Indeed, before becoming university teachers they had given no thought to what a university teacher should do to make teaching a success.

In the context of teachers' personal qualities, the focus groups understood the importance of having "good relationships" with students (skillful communication), and stressed the significance of having vast knowledge and experience as a university teacher (dignity). Similarly, tolerance for differences is an inseparable and often complicated part of a university teacher's work.

As a university teacher you have to be competent in establishing associations between the subject you teach and other world.

(University lecturer - T3)
A university teacher's patience has to be stretchy like an elastic ribbon for shorts.

(University lecturer - T1)

Being a university teacher is like reforming one's own character.

(University lecturer - T3)

The focus groups agreed that knowledge of the subject is very important but also expressed their conviction that a university teacher does not need to have ready answers to all the questions students ask, which is too much to expect, even for 'top-notch' specialists. Nevertheless, a teacher should have the courage to admit ignorance.

On one hand, I suppose that university teachers should be top specialists in their field so that they would readily answer all questions yet, on the other, a question may always be put that I cannot answer.

(University lecturer - T2)

True enough, a university teacher has to be an erudite educationalist and a leading expert in their own field of research but it will not happen overnight.

(University lecturer - T1)

The focus groups had concluded when reflecting on the ideal 'before' that first and foremost, the ideal teacher needs to have an excellent knowledge of the subject, followed by personal qualities and didactic knowledge. When reflecting on the ideal 'now' the conclusions were that after they had experienced active teaching, knowledge of the subject and didactic knowledge had changed places in the sequence of significance. They now considered didactic skills as the most essential role in teaching and knowledge of the subject ranked as the least as the requirements set to it were not as high as when first beginning to teach. When reflecting on the causes of changes, the focus groups admitted that the teaching process had had a major impact on the change of the image of an ideal university teacher. In addition, other causes included a possible impact of various in-service trainings, as well as learning from colleagues' experience in the course of work. Various personal reasons like an increase in confidence, internal development, maturing as a personality etc. were mentioned less often. Independent work with literary sources, participation in conferences, contacts with teaching traditions of other universities etc. were also brought out.

The majority of the lecturers in the focus groups took as 'natural' the importance of didactic knowledge because only during practical teaching is the teaching process visible from the teacher's viewpoint.

While teaching, a direct need for didactic knowledge and skills is surfacing and the daily teaching experience constantly raises various problems to be solved. 
As a university teacher, whatever may happen at a lecture, I always wish to come out clean on it, or "land on all four paws", so to say.

(University lecturer - T2)

Didactic knowledge is particularly important for teachers seeking to remain firm in their decisions and attempting to make well-founded and considered choices. The focus groups also pointed out that a broader outlook on life is required because knowledge of the subject alone is not sufficient.

University teachers clearly indicated that it was good to teach a relaxed and harmonious audience. Discussions pointed out that there would be fewer problems if university teachers knew the right tactics for teaching and if the whole teaching process was thought through (however hard to put into practice).

\section{DISCUSSION}

This research demonstrated that there was no single image of the ideal university teacher, nor is the image a static collection of characteristics. Ideals or possible selves, similar to identity, are dynamic and their origins and longevity are influenced by personal goals, interactions and outcomes that occur within a relevant environment (Hamman et al., 2010). Ideal is an image that can change as teachers' professional identities develop over time and through teaching experience.

In the reflection groups we asked the participants to reflect on the ideals in a time-frame and to discuss in depth the reasons that might have brought about changes in the ideal university teacher.

Before having any teaching experience, university lecturers pointed out the necessity of having excellent knowledge of the subject was the most significant factor, which is in accordance with earlier investigations (Åkerlind, 2007; Åkerlind, 2003)

Likewise, the concept of good teaching only becomes clearer in the process of teaching (Brilhart, 2010). For this reason we conclude the participants evidently proceeded from their own earlier learning experience when the university teacher was initially perceived as an excellent specialist in their field of research. We base this conclusion on the idea that participants had, when describing an ideal teacher, focused on lecturers who had been their teachers. Top scientists in their field were repeatedly mentioned as ideal university teachers whose example could have shaped the model of an ideal university teacher for participants.

However, after having obtained teaching experience, the necessity for didactic knowledge and skills gains more recognition than before teaching. Aspects related to planning and structuring the teaching process are viewed in a broader perspective through one's own experience. Alongside evaluation and transmission of knowledge of the subject, tasks of equal importance are to find out how students understand the subject and to support their learning how the subject being taught is structured and organized. This outcome accords with Karjalainen and Nissilä (2008) who suggest that with increased teaching experience, teachers appreciate good teaching skills. These skills enable teachers to explain content clearly, find core learning problems and also find the best ways to attain their goals.

University teachers with definite teaching experience render the ability of flexible reaction as an important teaching skill alongside the ability to the particular traits of every learner and finding appropriate methods to cope with a situation or individual's needs.

In both the 'before' and 'now' ideals, personal qualities were found to be equally important although, at the same time, the sequence of presentation of personality characteristics changed. Whereas dignityrelated personal characteristics had initially been ranked first, skillful communication and interesting personality now came to the fore. One reason for dignity becoming less important may be due to students' 'before' viewpoint that prestige and maturity are attributes that distinguish teachers from students. Only over time and acquired experience does the practicality of personal growth, storing wisdom, lived experience and a world outlook replace the allure of prestige. This result is compatible with Sherman's (2004) assertion that teaching requires wisdom, and not just book or technical knowledge. At the same time the significance of dignity may have decreased because, as university teachers, the participants no longer considered evaluating dignity as an individual personal quality as an essential activity.

Characteristics like skillful communication and interesting personality were considered important in both the 'before' and 'now' ideals. They were essential during the 'before' period as they exerted immediate influence on the students' learning processes. University teachers regard skillful communication as the most important personal characteristic since both teaching and learning are fostered by a favourable atmosphere in class and empathy between both parties. In addition, excellent teacher-student interaction allows the university teacher to get adequate feedback, contributing to the development of professional identity of the teacher. In the background of personal characteristics, experienced university teachers may feel the need for maintaining their individuality and act in accordance with their self-concept. 
The low ranking of the characteristic of excellent knowledge of the subject in the 'now' ideal does not infer that experienced university teachers would regard knowledge of the subject as insignificant. While teaching, a need is felt for a broader world outlook, which helps establish new and interesting associations for better teaching of the subject, and coping with the teaching process may give the teacher a feeling of satisfaction. Based on the participants' responses, in the course of accumulating teaching experience, university teachers become increasingly aware that to be a good teacher one does not need to be a top scientist in one's field. Being adequately competent in the subject and keeping abreast with world scientific achievements in the field are sufficient. Indeed, since university teachers cannot know everything, they need to acquire alternative methods in order to more qualitatively transmit the existing knowledge.

Teaching experience not only has a defining impact on the ideal image of a university teacher but is also the initial agent of change of professional identity. While inexperienced university teachers ranked knowledge of the subject as the most highly evaluated characteristics then experienced teachers give greater importance to growth of teaching experience, didactic knowledge and skills.

\section{LIMITATIONS AND CONCLUSION}

This research offers an opportunity to examine those factors, which have an impact on the development of the university teacher's professional identity. As researchers, we understand that the current investigation has limitations. Research outcomes could have been influenced by participants earlier attending courses on pedagogy (of which the researchers were unaware) and the fact that the participating university teachers were members of three reflection training groups.
Despite these limitations, this research yields important information that confirms the process of university teachers' identity development. In addition, as researchers, we find that when supporting the development of professional identity it is important to offer a possibility of reflection on ideals of both one's past and present to all teaching staff in the higher education teaching process. Reflection on the ideals may be beneficial for teaching staff and may assist them in anticipating future actions in useful ways (Conway, 2001) and looking for an ideal identity may aid university teachers in progressing toward a desired notion of the teachers they would like to become (Alsup, 2006). Participating in this research and taking the opportunity of reflecting on the ideals of a university teacher enabled the participants to observe their own learning and teaching from different perspectives. This enabled them to become more aware of qualities that are appreciated in a university teacher and that may have an impact on the development of their professional identity.

The research outcomes confirm the assertion that alongside the development of professional identity and increase of teaching experience, the evaluation of didactic knowledge is also increasing.

Proceeding from this feature of didactic knowledge, we suggest similar research is necessary to discover at which development stage university teachers most acutely require help and support in enhancing their didactic skills, achieving the best outcomes, and find the best methods to do so.

\section{ACKNOWLEDGEMENTS}

This study was supported by Estonian Science Foundation 'Eduko' program. 


\section{REFERENCES}

Åkerlind, G.S. (2003). Growing and Developing as University Teacher - Variation in Meaning. Studies in Higher Education, $28,375-390$.

Åkerlind, G.S. (2007). Constraints on academics' potential for developing as a teacher. Studies in Higher Education, 32, 2137.

Akkerman, S.F., Meijer, P.C. (2011). A dialogical approach to conceptualizing teacher identity. Teaching and Teacher Education, 27, 308-319.

Alsup, J. (2006). Teacher identity discourses: Negotiating personal and professional spaces. Mahwah, NJ: Lawrence Erlbaum.

Archer, L. (2008). The new neoliberal subjects? Young/er academics' constructions of professional identity. Journal of education policy, 23, 265-285.

Arnon, S., Reichel, N. (2007). Who is the ideal teacher? Am I? Similarity and difference in perception of students of education regarding the qualities of a good teacher and of their own qualities as teachers. Teachers and Teaching: theory and practice, 13(5), 441-464.

Beauchamp, C., Thomas, L. (2010). Reflecting on an ideal: student teachers envision a future identity. Reflective Practice, 11(5), $631-643$

Beijaard, D., Meijer, P., Verloop, N. (2004). Reconsidering research on teachers' professional identity. Teaching and Teacher Education, 20, 107-128.

Beijaard, D., Verloop, N., Vermunt, J. (2000). Teachers' perceptions of professional identity: an exploratory study from a personal knowledge perspective. Teaching and Teacher Education, 16, 749-764.

Brilhart, D. (2010). Teacher Conceptualization of Teaching: Integrating the Personal and the Professional. Journal of Ethnographic \& Qualitative Research, 4, 168-179.

Clegg, S.(2008). 'Academic identities' under threat? British Educational Research Journal, 34, 329-345.

Cochran-Smith, M., Fries, M.K. (2001). Sticks, Stones, and Ideology: The Discourse of Reform in Teacher Education. Educational Researcher, 30(8), 3-15.

Coldron, J., Smith, R. (1999). Active location in teachers' construction of their professional identities. Journal of curriculum studies, 31(6), 711-726.

Conway, P. F. (2001). Anticipatory reflection while learning to teach: From a temporally truncated to a temporally distributed model of reflection in teacher education. Teaching and Teacher Education, 17(1), 89-106.

Day, C. (1998). Working with the different Selves of Teachers: beyond comfortable collaboration. Educational Action Research, 6(1), 255-273.

Farrell, T. S. C. (2011). Exploring the professional role identities of experienced ESL teachers through reflective practice. System, 39(1), 54-62.

Fletcher, S. (2000). A role of imagery in mentoring. Career Development International, 5(5), 235-243.

Flores, M, A., Day, C. (2006). Contexts which shape and rehape new teachers' identities: A multi-perspective study. Teaching and teacher Education, 22, 219-232.

Freese, A. (2006). Reframing one's teaching: Discovering our teacher selves through reflection and inquiry. Teaching and Teacher Education, 22, 110-119.

Gee, J. P. (2001). Identity as an analytic lens for research in education. In W.G. Secada (Eds.), Review of research in education. (25), 99-125 Washington, DC: American Educational Research Association.

Hamman, D., Gosselin, K., Romano, J., Rommel, B. (2010). Using Possible-selves theory to understand the identity development of new teachers. Teaching and Teacher Education, 26, 1349-1361.

Hsieh, H. F., Shannon, S. E. (2005). Three approaches to qualitative content analysis. Qualitative Health Research, 15(9), $1277-1288$.

Hermans, H., Dimaggio, G. (2007). Self, Identity, and Globalization in Times of Uncertainty: A Dialogical Analysis. Review of General Psychology, 11(1), 31-61.

Johns, C. (1995). The Value of Reflective Practice for Nursing. Clinical Nurse, 4, 23-30.

Karjalainen, A., Nissilä S.P. (2008). Designing and Piloting 60-Ects Credit Teacher Education Program for University Teachers. In. K. Gerber (ed.), Personal- und organizationsentwicklung in Einrichtungen der Lehre und Forschung 5. Bielefelt: Universitatsverlag Webler.

Korthagen, F., Vasalos, A. (2005). 'Levels in reflection: core reflection as a means to enhance professional growth'. Teachers and Teaching, 11, 47-71.

Kreber, C. (2010). 'Academics' teacher identities, authenticity and pedagogy'. Studies in Higher Education, 35(2), 171-194. 
Lamote, C., Engels, N. (2010). The development of student teachers' professional identity. European Journal of Teacher Education, 33(1), 3-18.

Laurila \& Kukkonen (2003). Evolving Professional Identity: Awareness of Self-Discrepancies as a Spur for Learning. Proceedings of the conference "Teaching and Learning in Higher Education: New Trends and Innovations. University of Aveiro, 13.-17. April 2003.

Lea, M.R., Stierer, B. (2009). Lecturers' everyday writing as professional practice in the university as workplace: new insights into academic identities. Studies in Higher Education, 34(4), 417-428.

Loughran, J. (2002). Effective Reflective Practice: In Search of Meaning in Learning about Teaching. Journal of Teacher Education, 53(1), 33-43.

MacLure, M. (1993). Arguing for your self: Identity as an organising principle in teachers' jobs and lives. British Educational Research Journal, 19(4), 311-322.

Markus, H., Nurius, P. (1986). Possible selves. American Psychologist, 41(9), 954-969.

Miron, M. (1983) What makes a good teacher? Higher Education in Europe, 8(2), 45-53.

Rabiee, F. (2004). Focus-group interview and data analysis. Proceedings of the Nutrition Society, 63, 655-660.

Ruyter, D., Conroy, J. (2002). The Formation of Identity: The Importance of Ideals. Oxford Review of Education, 28(4), 509522.

Sherman, S. (2004). Responsiveness in teaching: Responsibility in its most particular sense. The Educational Forum, 68, 115-124.

Stenberg, K. (2010). 'Identity work as a tool for promoting the professional development of student teachers'. Reflective Practice, 11, 331-346.

Strage, A. (2008). Traditional and non-traditional college students' descriptions of the "ideal" professor and the "ideal" course and perceived strengths and limitations. College Student Journal, 42(1), 225-231.

Strauss, A., Corbin, J. (1990). Basics of qualitative research: Grounded theory procedures and techniques. Newbury Park, CA: Sage Publications, Inc.

Swennen, A., Volman, M., van Essen, M. (2008). The development of the professional identity of two teacher educators in the context of Dutch teacher education. European Journal of Teacher Education, 31(2), 169-184.

Thomas, L., Beauchamp, C. (2011). Understanding new teachers' professional identities through metaphor. Teaching and Teacher Education, 27(4), 762-769.

Verhofstadt- Deneve, L. (2003). The psychodramatical “Social atom method”: Dialogical self in dialectical action. Journal of Constructivist Psychology, 16, 183-212.

Wenger, E. (1998). Communities of Practice: Learning, meaning and identity. New York: Cambridge University Press.

* The publishing of this paper was supported by European Social Fund. 